\title{
Toxic epidermal necrolysis induced by lansoprazole*
}

\section{Necrólise epidérmica tóxica induzida pelo lansoprazol}

\author{
Tainá Scalfoni Fracaroli ${ }^{1}$ \\ João Luz Sodré ${ }^{2}$ \\ Alexandre Gripp ${ }^{4}$
}

\author{
Ludmilla Queirós Miranda ${ }^{1}$ \\ Mário Chaves ${ }^{3}$
}

\begin{abstract}
Toxic epidermal necrolysis is a rare, severe cutaneous reaction, mostly caused by drugs. It affects the skin and mucous membranes, with involvement of more than $30 \%$ of body surface. We describe the case of a young woman, previously healthy, who developed skin detachment of more than $90 \%$ of the body surface 15 days after being administered lansoprazole for peptic disease. The treatment consisted in discontinuation of the drug involved and early administration of intravenous human immunoglobulin, which led to a satisfactory outcome of the case, substantiating the impact of early diagnosis and treatment on the morbidity and mortality of these patients.
\end{abstract}

Keywords: Epidermal necrolysis, toxic; Immunoglobulins, intravenous; Proton pump inhibitors

Resumo: A Necrólise epidérmica tóxica é uma reação cutânea rara, causada principalmente por drogas. Envolve pele e mucosas, com acometimento superior a 30\% da superfície corpórea. Ilustramos um caso de uma paciente jovem, previamente hígida que desenvolveu necrólise epidérmica tóxica, com descolamento superior a 90\% da superfície corpórea, 15 dias após o início de lanzoprazol para doença péptica. O tratamento consistiu na interrupção do uso da droga implicada e administração precoce de imunoglobulina humana por via venosa, que levou a um desfecho satisfatório do caso, demonstrando o impacto do diagnóstico e tratamento precoces sobre a morbimortalidade destes pacientes.

Palavras-chave: Imunoglobulinas intravenosas; Inibidores da bomba de prótons;

Necrólise epidérmica tóxica

\section{INTRODUCTION}

Toxic epidermal necrolysis (TEN) is a rare disorder, having significant morbidity and over $30 \%$. mortality ${ }^{1}$ It is characterized by extensive apoptosis of keratinocytes, leading to epidermal detachment and mucosal involvement. ${ }^{2}$
The Stevens-Johnson syndrome (SJS) and TEN represent severe variants of the same process, due to etiopathogenic, clinical and histopathological similarities. These entities differ only in the percentage of body surface involved: a detachment below 10\%

Received on 12.11.2011.

Approved by the Advisory Board and accepted for publication on 16.01.2012.

* Study carried out at the Teaching Hospital, State University of Rio de Janeiro (Hospital Universitário Pedro Ernesto - Universidade do Estado do Rio de Janeiro - HUPE - UERJ) - Rio de Janeiro (RJ), Brazil.

Conflict of interest: None

Financial funding: None

MD - Graduate student in Dermatology at the Teaching Hospital, State University of Rio de Janeiro (Hospital Universitário Pedro Ernesto - Universidade do Estado do Rio de Janeiro - HUPE-UERJ) - Rio de Janeiro (RJ), Brazil.

Resident in Dermatology at the Teaching Hospital, State University of Rio de Janeiro (Hospital Universitário Pedro Ernesto - Universidade do Estado do Rio de Janeiro - HUPE-UERJ) - Rio de Janeiro (RJ), Brazil.

MD - Dermatologist and research assistant at the Dermatology Service, Teaching Hospital, State University of Rio de Janeiro (Hospital Universitário Pedro Ernesto - Universidade do Estado do Rio de Janeiro - HUPE-UERJ) - Rio de Janeiro (RJ), Brazil.

MD - Master's degree in Dermatology - Assistant Professor in Dermatology and responsible for the Dermatology Infirmary at the Teaching Hospital, State University of Rio de Janeiro (Hospital Universitário Pedro Ernesto - Universidade do Estado do Rio de Janeiro - HUPE-UERJ) - Rio de Janeiro (RJ), Brazil. 
represents SJS, 10-30\% overlapping of both and above $30 \%$ it characterizes TEN. ${ }^{3}$

The main factors involved in the etiology are drugs, mainly antibiotics, anticonvulsants, oxicam family of nonsteroidal anti-inflammatory drugs and allopurinol. The proton pump inhibitors (lansoprazole and omeprazole) are considered of low risk. ${ }^{4-6}$ Cases of TEN have been attributed to several new drugs, given that the ones with longer half-life pose higher risk.

The pathogenesis is not fully understood and involves the inability to detoxicate reactive metabolites of drugs, genetic susceptibility and immune factors related to cellular apoptosis. The main pathway of cell death in this case is the interaction of Fas receptor and Fas ligand on the surface of the keratinocyte, since the latter acquires an increased expression on the surface of keratinocytes in TEN. ${ }^{7.8}$

The clinical signs begins, on average, one week after administration of the drug, and it may range from 7 to 21 days in a first exposure. In a reexposure, the onset happens earlier, and it may happen in 2 days. ${ }^{2,4}$ It is common that unspecific symptoms such as fever, sore throat, stinging eyes and vagina, precede cutaneous manifestations by a few days. The first lesions tend to happen on the trunk, and are usually erythematous papules or purpuric macules, irregular in shape and size, which tend to coalesce. The progression of the disease, if the offending drug is not removed, occurs from 2 to 5 days or in hours; it rarely takes more than one week. The lesions become greyish red, there is intense necrosis of the whole epidermis, and flaccid blisters are formed, leaving large denuded areas. There is oral mucosa, ocular and genital involvement in more than $90 \%$ of the patients with extensive and painful erosions which lead to lip crusts, odynophagia, photophobia, dysuria and painful evacuations. ${ }^{1,3}$ Systemic manifestations happen due to acute cutaneous failure, which results in water and electrolytic disorder, hypovolemia, renal failure, thermoregulatory unbalance and higher predisposition to sepsis. ${ }^{1}$

There is a severity score for TEN (SCORTEN), which may be useful to assess the prognosis of these patients, if performed within the first 48 hours of onset (Table 1). ${ }^{7}$ Factors such as lymphadenopathy, increased transaminasis and neutropenia also imply worse prognosis. ${ }^{1,3}$ Management in the acute stage involves prompt identification and withdrawal of the culprit drug, support therapy in intensive care unit or burn intensive care and eventual specific drug therapy. Early ophthalmologic evaluation is important to avoid late complications, such as synechia and amaurosis. ${ }^{3,9}$

Systemic corticosteroids were the main therapy over decades. Currently, their use is controversial,
TABLE 1: Score of severity of TEN - SCORTEN

\begin{tabular}{ll}
\hline Prognostic factors & Points \\
\hline Age $>40$ years & 1 \\
Tachycardia $>120 \mathrm{bpm}$ & 1 \\
Neoplasia & 1 \\
Initial detachment $>10 \%$ & 1 \\
Serum urea $>10 \mathrm{mmol} / \mathrm{L}$ & 1 \\
Serum bicarbonate $<20 \mathrm{mmol} / \mathrm{L}$ & 1 \\
Blood glucose $>14 \mathrm{mmol} / \mathrm{L}$ & 1 \\
& \\
SCORTEN & Mortality (\%) \\
$0-1$ & 3 \\
2 & 12 \\
3 & 35 \\
4 & 58 \\
$\geq 5$ & 90 \\
\hline
\end{tabular}

some experts suggest there is increased risk of sepsis and death, while others show that short course of high dose, at the onset, may be beneficial. ${ }^{9,10}$ The administration of high doses of intravenous immunoglobulin (IVIG) seems to be a promising alternative, as it showed reduction in mortality in some studies. Its probable mechanism of action consists in blocking the Fas receptor-Fas ligand binding, thus inhibiting the apoptosis of keratinocytes. The dose has not been established yet, but the literature shows a higher benefit with the early administration of high doses $(2-3 \mathrm{~g} / \mathrm{kg}$ divided in 3-4 days). ${ }^{4,9,10}$ Other drugs may be used, such as cyclosporine, cyclophosphamide and TNF-alpha antagonists. ${ }^{4,7}$

\section{CASE REPORT}

A previously healthy, 23-year-old woman, began to have ocular and vaginal itching and later symmetrical erythematous macules appeared on the limbs, mainly hands and feet. Within 7 days there was significant spread of lesions, which evolved into blisters. She sought the emergency care unit, where prednisone $2 \mathrm{mg} / \mathrm{kg}$ was administered. After 2 days, she was transferred to our service. She reported use of lansoprazole 15 days before the appearance of the lesions.

On examination, the patient was pale $2+/ 4+$, febrile and tachycardic. Epidermal detachment involved more than $90 \%$ of the body surface, and there were some areas of erosion (Figures 1 and 2). Mild involvement of the oral mucosa and lips with crust formation. She was admitted to the intensive care unit, lansoprazole was stopped and intravenous immunoglobulin, $2 \mathrm{~g} / \mathrm{kg}$ was administered for 3 days, in addition to skin debridement and daily dressings. The patient developed significant reepithelialization in 15 days (Figures 3 and 4). After two months, she presents only residual hyperchromic macules. 


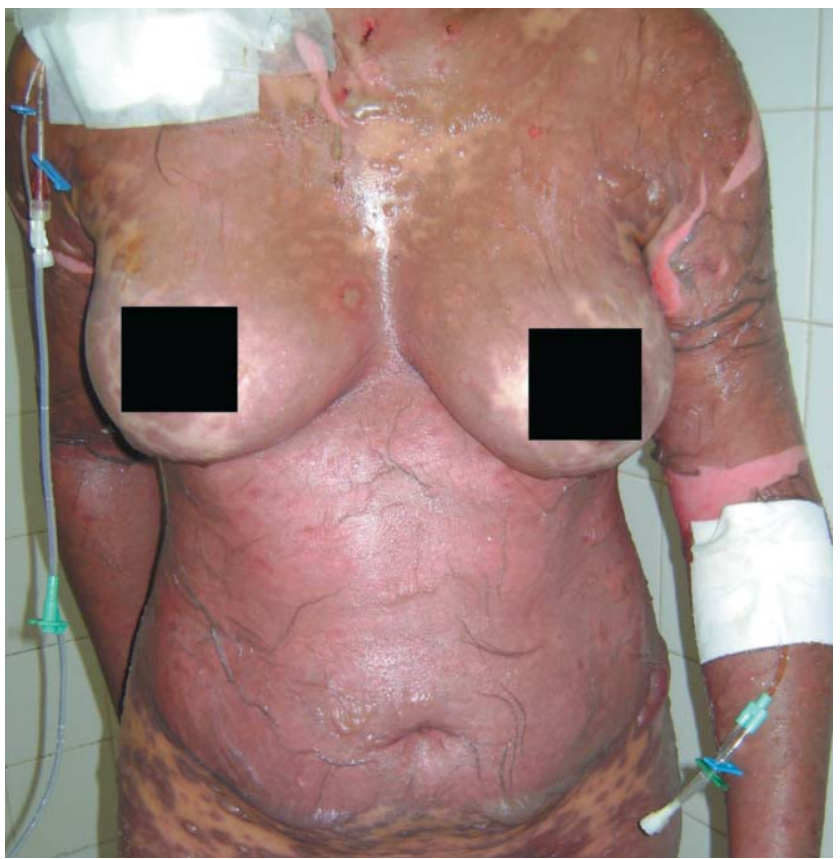

FiguRE 1: Extensive epidermal detachment

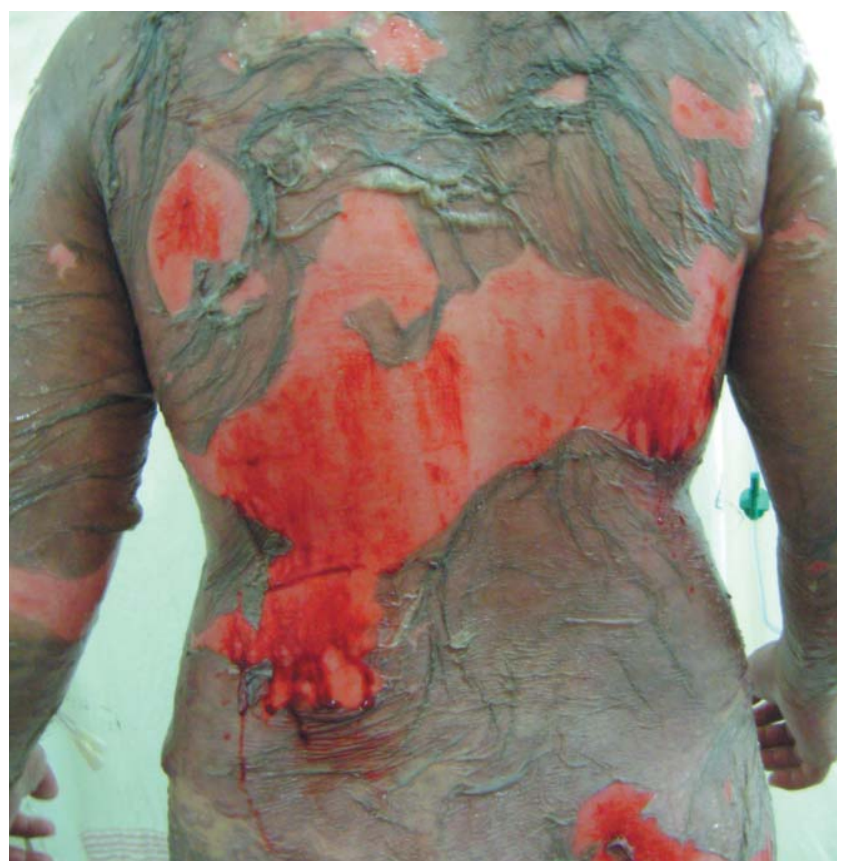

FiguRE 2: Erosion in areas of more pressure

\section{DISCUSSION}

The proton pump inhibitors are drugs which are little related to the development of TEN, and only 5 cases have been reported in the literature to date. Nonetheless, as they are often used, they may not be considered as cause of pharmacodermia. Our patient showed symptoms 15 days after the administration of lansoprazole and had nonspecific complaints 1 day before the onset of skin lesions, as described in the

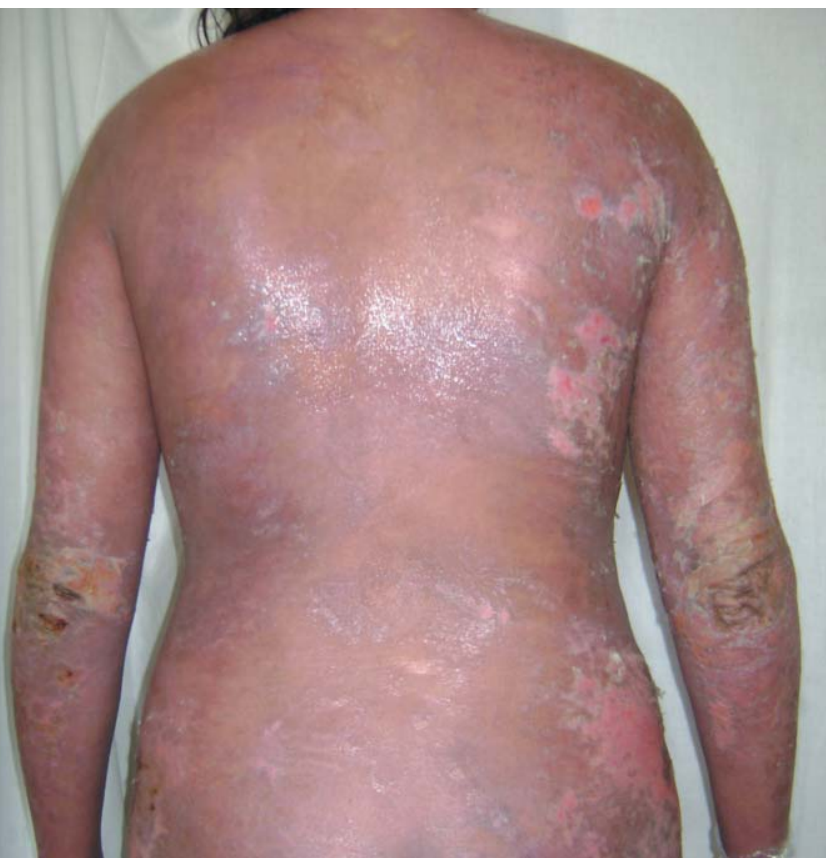

Figure 3: Evolution: 15 days after admission

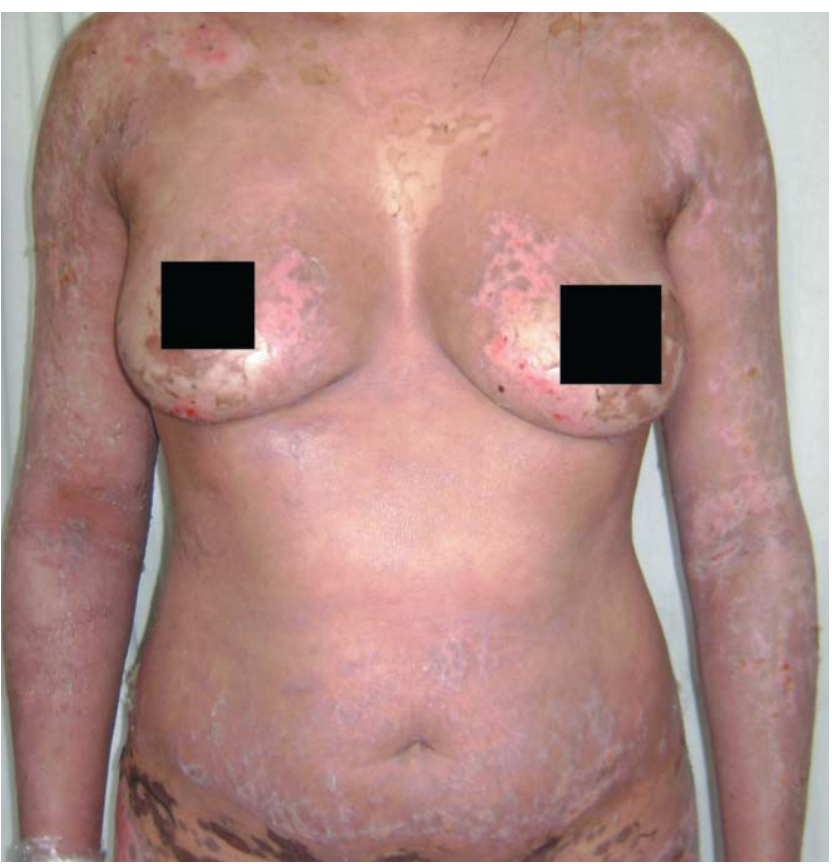

FIGURE 4: Progressive reepithelization

literature. However, the first lesions were on the extremities and there was palmoplantar involvement, which is not frequent. Although the patient has presented more than $90 \%$ of epidermal detachment, there were no severe systemic complications, and the process ended after withdrawal of the culprit drug and immunoglobulin administration.

We believe that SCORTEN is useful, but in this 
case it was not used because the patient was admitted nine days after onset of symptoms. Early ophthalmologic evaluation and daily eye care were performed, as ocular synechia is the main long-term sequela. Due to the involvement of the skin and mucous membranes (oral, ocular and genital), an interdisciplinary assessment is important.
The diagnosis is clinical and must not be delayed due to high mortality. It is hard to establish a therapy of choice for TEN, due to the rarity of the disorder and the difficulty of performing controlled clinical trials, but intravenous immunoglobulin is a promising therapeutic option, as there is evidence it may stop the necrosis process.

\section{REFERENCES}

1. Roujeau JC, Guillaume JC, Fabre JP, Penso D, Fléchet ML, Girre JP. Toxic epidermal necrolysis (Lyell Syndrome). Incidence and drug aetiology in France, 1981-85. Arch Dermatol. 1990;126:37-42.

2. Bastuji-Garin S, Rzany B, Stern RS, Shear NH, Naldi L, Roujeau JC. Clinical classification of cases of toxic epidermal necrolysis, Stevens-Johnson syndrome and erythema multiforme. Arch Dermatol. 1993;129:92-6.

3. Criado PR, Criado RFJ, Vasconcellos C, Ramos R0, Gonçalves AC. Reações cutâneas graves adversas a drogas - aspectos relevantes ao diagnóstico e ao tratamento - Parte I - Anafilaxia e reações anafilactóides, eritrodermias e o espectro clínico da síndrome de Stevens-Johnson \& necrólise epidérmica tóxica (Doença de Lyell). An Bras Dermatol. 2004;79:471-88.

4. Pereira FA, Mudgil AV, Rosmarin DM. Toxic epidermal necrolysis. J Am Acad Dermatol. 2007;56:181-200.

5. Thakor AS, Burke A, Handfield-Jones S, Sinha A, Palmer M, Burns A. Toxic epidermal necrolysis and neutropaenia: complications of omeprazole. Aust J Dermatol. 2009;50:207-10.

6. Heaton NR, Edmonds EV, Francis ND, Bunker CB, Bowling JC, Morar N. Fatal toxic epidermal necrolysis due to lansoprazole. Clin Exp Dermatol. 2004;29: 612-3.

7. Rajaratnam R, Mann C, Balasubramaniam P, Marsden JR, Taibjee SM, Shah F, et al. Toxic epidermal necrolysis: retrospective analysis of 21 consecutive cases managed at a tertiary centre. Clin Exp Dermatol. 2010; 35:853-862.
8. Marzano AV, Frezzolini A, Caproni M, Parodi A, Fanoni D, Quaglino P, et al Immunohistochemical expression of apoptotic markers in drug-induced erythema multiforme, Stevens-Johnson syndrome and toxic epidermal necrolysis. Int J Immunopathol Pharmacol. 2007;20:557-66.

9. Chave TA, Mortimer NJ, Sladden MJ, Hall AP, Hutchinson PE. Toxic epidermal necrolysis: current evidence, practical management and future directions. $\mathrm{Br} \mathrm{J}$ Dermatol. 2005; 153: 241-53.

10. Schneck J, Fagot JP, Sekula P, Sassolas B, Roujeau JC, Mockenhaupt M. Effects of treatments on the mortality of Stevens-Johnson syndrome and toxic epidermal necrolysis: a retrospective study on patients included in the prospective EuroSCAR Study. J Am Acad Dermatol. 2008;58:33-40.

\author{
MAILING ADDRESS: \\ Tainá Scalfoni Fracaroli \\ Avenida 28 de Setembro, 77 \\ Vila Isabel \\ 20551030 Rio de Janeiro, RJ \\ E-mail: tsfracaroli@yaboo.com.br
}

How to cite this article: Fracaroli TS, Miranda LQ, Sodré JL, Chaves M, Gripp A. Toxic epidermal necrolysis induced by lansoprazole. An Bras Dermatol. 2013;88(1):117-20. 